\title{
A Case of Kinship
}

\section{Onomasiological Explorations of KINSHIP in Old Frisian and Old English}

\author{
Rita van de Poel | ORCID: 0000-0001-5960-7913 \\ Leiden University Centre for the Arts in Society, Leiden University, \\ Leiden, Niederlande \\ g.i.van.de.poel@hum.leidenuniv.nl \\ Sander Stolk | ORCID: 0000-0003-2254-6613 \\ Leiden University Centre for the Arts in Society, Leiden University, \\ Leiden, Niederlande \\ s.s.stolk@hum.leidenuniv.nl
}

\begin{abstract}
This article describes onomasiological explorations of Old Frisian and Old English lexis in the semantic field of KINSHIP through a novel, digital approach. In connecting Old Frisian lexis, drawn from the Altfriesisches Handwörterbuch ( $A F W B$ ), to the overarching structure of $A$ Thesaurus of Old English (TOE), a dataset has been created that shares a semantic framework with the one existing for Old English lexis. The connected resources are shared and analysed using the web application Evoke. Statistical data provided by this tool, such as the degree of lexicalization for this field, facilitates comparative analyses of the two historical languages. As this article demonstrates, the reuse of the onomasiological macrostructure of TOE offers new insights into linguistic and cultural aspects of these two languages and their language communities.
\end{abstract}

\section{Keywords}

onomasiology - KINSHIP - Old Frisian - Old English - Evoke - digital humanities linguistic linked data - thesaurus 
Since its publication in 1995, A Thesaurus of Old English (TOE) has been an asset to research into Old English language and culture. This lexicographic resource captures the early medieval English lexis (c.500-110o), which it does not order alphabetically, like most lexicographic works for Old English do, but onomasiologically: words are organized by means of an overarching topical structure, allowing users to go from meaning to words that express that meaning. In thus positioning words that are similar in meaning close to one another, including the grouping of synonyms, TOE has facilitated numerous word studies and semantic field studies ${ }^{1}$ and its contribution to Old English studies has been met with high praise from scholars (Dance, 1997: 312; Görlach, 1998: 398-399). Hence, the value of an onomasiological ordering of lexis has been demonstrated for Old English. As can be imagined, that value is not limited to this specific language.

Comprehensive thesauri such as $T O E$, in spite of their value for research, are scarce. The lack of such resources for entire languages is unsurprising: creating a thesaurus takes a considerable amount of time and effort. To illustrate, the creation of TOE (discussed in the contribution by Jane Roberts in this special issue) has taken a team of researchers, themselves drawing from available dictionaries of Old English, over fifteen years (Roberts, 1978). Amongst the languages which have hitherto not yet been captured in a thesaurus is Old Frisian. Yet, in this particular case, the characteristics of this language, combined with resources currently available, may pave the way towards an onomasiological ordering of its lexis in a shorter time than was needed for the creation of a thesaurus of Old English.

Parallels between Old English and Old Frisian have often been drawn and tend to be mentioned explicitly in books that serve as introductions to these languages (see Bremmer, 2009: 125-128; Baker, 2012: 7-8). Indeed, similarities between these 'sibling languages' exist on multiple levels -including their lexis. These parallels suggest that an onomasiological marcrostructure designed for Old English may form a good starting point for Old Frisian. Linking Old Frisian lexis to TOE, positioning words and word senses in appropriate locations of its macrostructure, may yield an onomasiological perspective on Old Frisian that is currently absent. Moreover, the placement of Old Frisian senses in

1 E.g. Hough (2007); Díaz-Vera (2011); Rauer (2017); Tissari (2017); Ojanguren López (2021); Scott (2021). 
this thesaurus is likely to also enable a comparison between these two closely related languages on onomasiological and lexico-semantic levels.

In this article, we describe preliminary work in connecting the Old Frisian lexis to $T O E$ and the use of the results to compare Old Frisian with Old English. For this purpose, we have used the Old Frisian lexis from one particular semantic field, namely that of KINSHIP, mainly represented in TOE by the category "02.03.02 Family/household". ${ }^{2}$ The connected resources are shared and analysed using the web application Evoke (Stolk, 2018). This application allows researchers to browse and analyse $T O E$ alongside additional content. In addition to discussing our findings in linking up Old Frisian information to the thesaurus, we will present comparative analyses of Old Frisian and Old English provided by the statistical data that Evoke offers, such as the degree of lexicalization of this specific field. Thus, we hope to answer, and nuance, the following questions regarding the semantic fields of KINSHIP in Old Frisian and Old English:

1. Can the Old Frisian lexis be allocated to the onomasiological macrostructure of $T O E$ ?

2. Can Evoke, in combination with TOE and the linked Old Frisian lexis, offer new insights into linguistic and cultural aspects of Old Frisian and, in contrast with Old Frisian, Old English?

The number of studies pertaining to Old Frisian linguistics is significantly smaller than those on Old/Middle English or Old/Middle High German (Bremmer, 2007: 55). Most Old Frisian linguistic research investigates a relatively limited aspect of the language or the texts: extensive, comprehensive research is scarce (Bremmer, 1992; 2021). Lexico-semantic Old Frisian studies are almost without exception short treatises on the characteristics of specific lexemes; only a few publications take an onomasiological perspective or comprise an entire semantic field. ${ }^{3}$ Although these studies in Old Frisian provide

2 "Family/household" in TOE. Identifier: 1108. Location: 02.03.02. IRI: http://oldenglishthesaurus.arts.gla.ac.uk/category/\#id=1108.

3 Noteworthy studies are Munske's seminal work on the Germanic vocabulary in the field of crime, in which he notes the parallels between the terminology in Old East Frisian and Old English (1973), Bremmer's work on verbal injury in late medieval Frisia (1998), Popkema's on the conceptualization of oaths (2007), and Hofmann's monograph on medieval everyday life as conceptualized in Old Frisian (2015). 
valuable insights into lexical expressions and their meanings, the lexicosemantic research in Old Frisian has hitherto mostly taken a traditional philological approach: they lack empirical or quantitative components. ${ }^{4}$

Research pertaining Old Frisian language is not only sporadic but also often undervalued - especially in the field of historical linguistics Old Frisian is considered to be neglected (Bremmer, 20og: 18; Stroh, 1985: 371; Munske, 2001: xiii; Salmons, 2007: 367 ). Digital environments for studying Old Frisian are scarce, hampering innovative research (such as comparative studies) of Old Frisian. ${ }^{5}$ Recently, however, a digital, lemmatized, and representative corpus of Old Frisian has been published online, a welcome lexicographic resource that can be used by both researchers and students (Van de Poel, 2019). This Corpus Oudfries contains a large sample of the Old Frisian language and can be searched on three linguistic levels (tokens, lemmata, and parts of speech) and on extra-linguistics levels (i.e. dialect and date). At this point in time, the corpus contains 235,462 tokens and 177 text witnesses from 11 manuscripts. Digital resources, such as this corpus and Evoke, provide new means for research into Old Frisian language and culture.

A semantic study of the domain of KINSHIP in Old Frisian has, to our knowledge, not been carried out before, although a limited number of studies are available that investigate individual lexemes ${ }^{6}$ and/or certain medieval Frisian legal aspects (Meijers, 1925; Kok, 1947; Boersma, 1961; Sterringa, 1998). For Old English, a comprehensive lexical investigation of kinship terminology has not been conducted either. Various studies have, however, been realized by anthropologists, traditionally the scholars that contributed the most to work on kinship systems and terminology. Lorraine Lancaster (1958), Henry Loyn (1974), and Georg Pfeffer (1987) are among the most influential scholars to have explored Anglo-Saxon kinship terms. Furthermore, certain lexical elements or subdomains within KINSHIP have been investigated for Old English (Spolsky, 1977; Bremmer, 1980; Lowe, 1993; Bajema, 1994; Fischer, 2006; Durkin, 2019).

Relevant semantic word field studies on KINSHIP that should be mentioned are descriptive and comparative studies by Ariane Diepeveen (2003)

4 An exception is Versloot's dissertation, which incorporates quantitative analyses to chart language change in $15^{\text {th }}$ century West Frisian (2008).

5 "The creation of a lemmatized (...) Old Frisian corpus would be invaluable for this investigation, as for so many others" (Colleran, 2017: 102). "Many instruments historical linguists have been accustomed to whilst studying older language stages are lacking or poorly available for Old Frisian" (Boutkan and Siebinga, 2005: vii).

6 E.g., Meijering (1985) discusses the etymology of kind, Bammesberger (1968) looks into the etymology of swager, and Pospelova (2018) examines Indo-European rules for compounding in Old Frisian kinship terms. 
and Susanne Zeilfelder (2015). Diepeveen provides a diachronic outline how the kinship terms of the (North and West) Germanic languages have evolved over the centuries. She includes almost all Germanic languages in her work, including Old English, but regrettably Old Frisian is absent. Zeilfelder's onomasiological work mainly focuses on the semantic development and etymology of German. She provides comparisons with and context from other Indo-European languages and to this end also describes Old English and Old Frisian lexemes. However, she does not do this consistently for each sense and/ or cognate word. The current study intends to work towards filling this lacuna and to explore how an onomasiological approach, and tools such as Evoke, can facilitate studies of Old Frisian terminology for KINSHIP.

Old Frisian is the term used to indicate the earliest version of the Frisian language, written between c.1100-1550. Only a fairly limited number of Old Frisian manuscripts (18) have come down to us, of which the texts are almost entirely juridical in nature. ${ }^{7}$ Besides the major juridical text collections, the largest body of Old Frisian texts consists of administrative documents (charters, wills, deeds), which represents about $50 \%$ of the entire collection of written Old Frisian words. ${ }^{8}$

The denominator "Old" for Old Frisian suggests that it was more archaic than its contemporary neighbouring languages (such as Middle English and Middle High German) and that it was linguistically compatible with, for example, Old English, Old High German, or Old Saxon. Scholars of Old Frisian have investigated the periodization of Old Frisian, which is complicated by the fact that dialectological differences in the language of the textual witnesses concur with the chronological differences: "some linguistic differences have to be interpreted in a chronological sense and some in a dialectological sense" (Versloot, 2004: 256). Rolf Bremmer summarizes the various chronological and dialectological research on Old Frisian and indicates that "the way in which languages are divided into periods depends on the criteria which one chooses in order to establish such periods" (2009: 125).

7 Bremmer (1992: 6-15) provides an overview of the most important Old Frisian texts and manuscripts.

8 According to Vries (2001: 594) 40\%, but closer to $50 \%$ based on token number estimates (own research, unpublished). 
It has generally been accepted that medieval Frisian texts can be divided into an older and a younger variety (classical/old vs. post classical/late) ${ }^{9}$ and that these periods more or less overlap with the division into regions or dialects. Arjen Versloot indicates that the dialect variety East Old Frisian dates mainly to the period 1300-1450 and was written in the present Dutch province of Groningen and in the German region of East Friesland (2004: 285). The second group originates from the province of Fryslân and was written in the period 1450-1525. He concludes: "Whatever periodisation scheme one prefers, the central conclusion is that the oldest Frisian attestations in the manuscripts represent a language that is fairly compatible with other Old Germanic languages" (2004: 285).

In this section we discuss our methodology for linking the Old Frisian lexis to $T O E$ as available in Evoke. In another article in this special issue, Katrien Depuydt and Jesse de Does describe their approach to a similar goal. They have experimented with a (semi-)automated method that matches Old Dutch words from the semantic field of KINSHIP with TOE. Our method, in contrast, involves manually matching dictionary senses to thesaurus categories and can be divided into the following steps:

1. Identifying Old Frisian lemmata on KINSHIP in the used source dictionary for Old Frisian.

2. Sense alignment: analysing the different senses of each lemma and matching these senses with a category in TOE or introducing a new category, resulting in a semantic classification.

3. Processing the alignment into Linguistic Linked Data and importing the work into Evoke.

\subsection{Identifying Old Frisian Lemmata on KINSHIP}

Creating a list of lemmata belonging to the semantic field of KINSHIP was accomplished by manually searching the Altfriesisches Handwörterbuch ( $A F W B$ ) and marking the words that belong to the semantic field of KINSHIP. The concise dictionary $A F W B$ covers the Old Frisian language from $1200-155^{\circ}$ and was compiled between 1959 and 2008 by Dietrich Hofmann and Anne Popkema. The Old Frisian words are provided with translations into Modern German. The compilers of $A F W B$ did not intend the dictionary to be comprehensive,

9 The terms "classical" and "post-classical" were coined by Sjölin (1966), who also raised the issue of the overlap between dialects and chronology. 
but included as many lemmata and sense distinctions as needed for its use as a reading companion to Old Frisian texts ( $A F W B$ : xxiii-Xxiv). The dictionary contains 11,254 headwords, of which $247(2 \%)$ were selected as they belonged to the semantic field of KINSHIP and were therefore eligible for linking to the TOE.

A dictionary entry in the $A F W B$ has the following format: the lemmata are printed in bold, a reference to dialect is printed in superscript (WL or OL), followed by the part of speech category, senses, sources (there is no indication which sense was found in which text source), composites and cross-references.

frouwe, frowe, frou ${ }^{\mathrm{WL}}$ f. 1) Frau; 2) Ehefrau; 3) Edelfrau, Fürstin; 4) Herrin; 5) die Jungfrau Maria; 6) Schwiegermutter -

Bas, BBr-D, BDg-U, BEm-E1E2, BFi-F, Bgr-J, BHm-J, BHua-H, BHub-H, (...). Komp.: ethelinges-, gā-, hāved-, hērskipes-, hūs-, jest-, jung-, klāster-, londes-, lond-, munekfrouwe

The head word is followed by subsidiary lemmata that pertain to phonological and/or orthographical (and often dialectal) variations of the head word. The lemmata within an entry are arranged in chronological order, which means that the earliest attestation is always the head word. In our methodology, the first lemma was selected for inclusion in the alignment. Thus, the earliest Old Frisian word forms have been imported into Evoke. The compilers of the $A F W B$ have harmonized the spellings of many word forms to ensure that lexemes belonging together can easily be retrieved.

An $A F W B$ lemma can have multiple senses, which are distinguished by numbers. Frequently, however, the senses of a lemma also contain commas that seem to indicate slightly overlapping meanings. Examples are: efterswesterling - "Andergeschwisterkind, Verwandter im dritten Grade" [second cousin, third-degree relative] and niftakind - "Grosskind, kind des Nichten" [grandchild, niece's child]. For the scope of the present study, we decided to consider these descriptive meanings as elaborations rather than distinct senses.

\subsection{Sense Alignment}

Three spreadsheets were developed in order to facilitate data entry and subsequent data conversion into Linguistic Linked Data, the interoperable data format used by Evoke. These spreadsheets represent the three main elements that are to be captured: lexical entries, senses, and concepts. Figure 1 shows the sheet for lexical senses. This sheet, which is pivotal in the alignment of the Old Frisian words and their senses with $T O E$, provides local identifiers for the current word (B) and for this word in a specific sense (A), the head word (D), the language code according to Iso 639 (E; here "ofs" for Old Frisian), and the 


\begin{tabular}{|c|c|c|c|c|c|c|}
\hline & A & B & c & D & E & $\mathrm{F}$ \\
\hline 1 & id & mentry-id & a [link] & aword & Flanguas: & Fconcept-id \\
\hline 2 & aftberen-s1 & aftberen & link & aftberen & ofs & http: $/ /$ oldenglishthesaurus.arts.gla.ac.uk/category/Hid $=1120$ \\
\hline 3 & aldaêm-s1 & aldaêm & link & aldaêm & ofs & 14 \\
\hline 4 & aldafeder-s1 & aldafeder & link & aldafeder & ofs & http://oldenglishthesaurus.arts.gla.ac.uk/category/\#id=1183 \\
\hline 5 & aldemôder-s1 & aldemôder & link & aldemôder & ofs & http://oldenglishthesaurus.arts.gla.ac.uk/category/\#id=1184 \\
\hline 6 & alderlâs-s1 & alderlâs & link & alderlâs & ofs & http://oldenglishthesaurus.arts.gla.ac.uk/category/\#id=1124 \\
\hline 7 & alder-53 & alder & link & alder & ofs & http://oldenglishthesaurus.arts.gla.ac.uk/category/\#id=1183 \\
\hline 8 & alder-\$4 & alder & $\underline{\text { link }}$ & alder & ofs & http://oldenglishthesaurus.arts.gla.ac.uk/category/\#id=1185 \\
\hline 9 & alder-55 & alder & link & alder & ofs & http://oldenglishthesaurus.arts.gla.ac.uk/category/Hid=1109 \\
\hline 10 & âthum-s1 & athum & link & âthum & ofs & http://oldenglishthesaurus.arts.gla.ac.uk/category/Hid=1262 \\
\hline 11 & âthum-s2 & âthum & link & âthum & ofs & http://oldenglishthesaurus.arts.gla.ac.uk/category/Hid=1262 \\
\hline 12 & basterdbrôther-s1 & basterdbrôther & link & basterdbrôther & ofs & http://oldenglishthesaurus.arts.gla.ac.uk/category/mid=1143 \\
\hline 13 & basterd-s1 & basterd & link & basterd & ofs & http://oldenglishthesaurus.arts.gla.ac.uk/category/Hid=1141 \\
\hline 14 & basterdswester-s1 & basterdswester & link & basterdswester & ofs & 3 \\
\hline 15 & bênene burch-s1 & bênene burch & link & bènene burch & ofs & http://oldenglishthesaurus.arts.gla.ac.uk/category/\#id=1787 \\
\hline 16 & bêneteburch-s1 & bêneteburch & link & bêneteburch & ofs & http://oldenglishthesaurus.arts.gla.ac.uk/category/\#id=1787 \\
\hline
\end{tabular}

FIGURE 1 Spreadsheet used in recording Old Frisian senses and the concepts to which they relate

identifier for the semantic category (F) in which the sense is to be positioned. The identifier of a category can be either an existing one from TOE (a web address also referred to as an IRI) or a newly coined category identified by a number and defined on the sheet for lexical concepts - including where this newly defined category fits into the TOE taxonomy.

The following activities are involved in assigning the senses of the Old Frisian lexemes to appropriate categories in TOE (either existing ones or new ones that add a further degree of specialization):

- Record the lemma and its Modern German senses in the spreadsheets.

- Translate Modern German sense definitions into Modern English. ${ }^{10}$

- Locate suitable TOE categories by

a) browsing the taxonomy of $T O E$

b) searching for categories that contain keywords from the translated Modern English definitions of the lemma, and

c) searching for the Old English cognates, if any, and marking the TOE categories at which they are positioned.

- Record matching TOE categories in the spreadsheets. When no matching $T O E$ category is available for a sense, create a new category in the spreadsheet and position that category in the TOE taxonomy by recording its superordinate category.

- Determine whether Old English cognates appear in more than one category, since this could imply that the Old Frisian lexeme under investigation would also have to be assigned to these other categories in order to facilitate contrasting the two languages. ${ }^{11}$

$10 \quad D W D S$ has been used to examine the German translations.

11 We elaborate on choices made during the classification process in Appendix A. 


\subsection{Processing the Alignment for Use in Evoke}

In order to transform the three spreadsheets to Linguistic Linked Data, we have employed the conversion tool OpenRefine along with its RDF plugin. The conversion logic for these sheets has been made publicly available. ${ }^{12}$ Each row in the sheet for lexical senses is transformed into an instance of a data element as defined in OntoLex, an interoperable model that has been designed specifically for capturing linguistic data, such as lexical entries and their senses. ${ }^{13}$ The resulting Linguistic Linked Dataset has been imported into the online repository of Evoke.

Numbers on the created dataset, which is now publicly available in Evoke, are as follows: 28 o lexical senses on KINSHIP, from 247 Old Frisian lemmata, have been aligned with TOE categories (see Appendix B). ${ }^{14}$ The majority of these senses have been allocated to the semantic field "O2.03.02 Family/household", as the following overview shows:

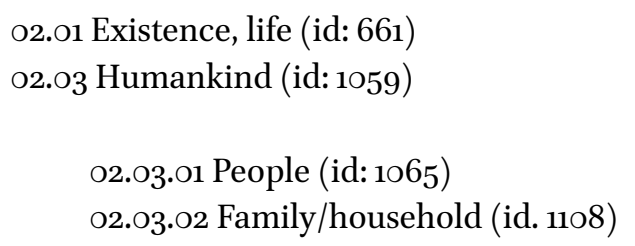

12.o9 Marriage, state of marriage (id: 186o2)

\author{
21 senses \\ 2 senses + those in \\ subfields (below) \\ 31 senses \\ 215 senses
}

11 senses

Since "O2.03.02 Family/household" represents the core of Old Frisian terminology on KINSHIP, this case study concentrates its onomasiological analyses on this semantic field.

Old Frisian senses placed under "02.03.02 Family/household" have either been allocated to already existing TOE categories (132 senses to 70 TOE categories) or to categories newly introduced into the TOE taxonomy (83 senses to 57 new categories). Originally, the field "O2.03.02 Family/household" contained a total of 175 categories with 324 recorded Old English senses. An overview

\footnotetext{
12 https://github.com/ssstolk/oldfrisian-kinship/.

13 OntoLex-Lemon: Lexicon Model for Ontologies, $W_{3} C$. http://www.w3.org/2016/o5/ ontolex/ (10 May 2016).

14 The dataset "Old Frisian: Kinship", containing 247 Old Frisian lemmata, is now publicly available in Evoke: http://evoke.ullet.net/content.
} 
Old English Old Frisian

$\begin{array}{lll}\text { number of lemmata } & 294 & 200 \\ \text { number of senses } & 324 & 215 \\ \text { number of categories w/ senses allocated to them } & 175 & 127\end{array}$

of these numbers is provided in Table 1. A substantial number of categories from this field in the expanded taxonomy have solely Old Frisian or solely Old English senses assigned to them (162 out of a total of 232 categories, or $70 \%$ ). In the field of KINSHIP, then, the recorded vocabularies of these kindred languages contain many differences in denotations and nuances of words. We will elaborate on some of the more apparent differences in our discussion of the distribution of Old Frisian lexis over the various semantic subfields of "O2.03.02 Family/household", in section 6.4.

\subsection{Locating Old Frisian Words, Their Synonyms, and Cognates}

As a consequence of the categorization of the Old Frisian lexis with the macrostructure of TOE, the web application Evoke can offer scholars a seamless integration of Old English and Old Frisian lexis for the field of KINSHIP. Thus, not only words for a given concept can be obtained for either language, but also synonyms and possible translations between them. Such an integrated overview of this information can be activated by selecting both relevant datasets in Evoke (i.e. TOE and the Old Frisian dataset newly created for this research). When subsequently opening a category such as "O2.03.02.03.03 Forefather, ancestor" in the user interface of the application, ${ }^{15}$ it is revealed which words were used to express this concept in both Old Frisian and Old English. The list presented in Figure 2 shows six different Old English words for this concept (including ërfeeder and ieldra) compared to three for Old Frisian (viz. alder, forefeder, forefirdera). These words are grouped by language and sorted alphabetically.

The integration of Old Frisian and Old English into Evoke facilitates the comparison of the relationship between the lexicons of both languages. Cognates are words within the same language or in different languages that have a

15 "Forefather, ancestor" in TOE. Identifier: 1178. Location: 02.03.02.03.03. IRI: http://old englishthesaurus.arts.gla.ac.uk/category/\#id=1178. 
all $>$ o Creation $>$ o Humankind $>$ o Family/household $>$ o Ancestry, descent $>$ o Forefather, ancestor

\begin{tabular}{|c|c|c|c|}
\hline - Forefather, ancestor & $i$ & $\underline{\underline{N}}$ & • $\quad$ \\
\hline noun æ̂rfæder & & pootry rare & Ord Engliath \\
\hline noun cnēowmæ̂g & & poetry & Ord English \\
\hline noun ealdfæder & & & 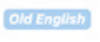 \\
\hline noun forpfeder & & & आव हnolish \\
\hline noun ieldra & & & का हnoliats \\
\hline noun lēodfruma & & pootry & Ord Engluth \\
\hline noun alder & & & 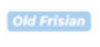 \\
\hline noun forefeder & & & 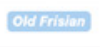 \\
\hline noun forefirdera & & & Oाव Fin: \\
\hline Show more from this domain & & & \\
\hline
\end{tabular}

FIGURE 2 List in Evoke of Old English and Old Frisian words denoting “O2.03.02.03.03 Forefather, ancestor"

common etymological origin, and therefore resemble each other to a greater or lesser extent in form (Schmitt, 1997: 209; Otwinowska-Kasztelanic, 2011: 4). Awareness of cognates enhances the ability to learn another language - in this case, learning Old Frisian will be easier for someone who is familiar with Old English, and vice versa (Schmitt, 1997: 209; Otwinowska-Kasztelanic, 2011: $4-5) \cdot{ }^{16}$ Additionally, finding cognate words in a set of languages is the first step in the comparative method for historical linguists, allowing them to study the development of languages and the reconstruction of common ancestors (Baldi, 2011: 1-16; Trask, 2015: 198-233). Figure 3 lists the various synonyms (in Old English as well as Old Frisian) for Old English ealda feeder. Here, Old Frisian aldafeder is a cognate of the Old English word that is closest in form: ealda fceder. Similarities such as these, i.e. in both form and meaning, facilitate detection of cognates.

\subsection{KINSHIP Terminology: Cultural Lexical Research of Cognates}

Onomasiological ordering of lexis can be useful for cultural lexical research. KINSHIP terms are "ways in which people classify their kinship universe" and as such provide clues to the nature of a kinship system in a society as well as

16 Summary of other cognates research in Friel and Kennison (2001). 


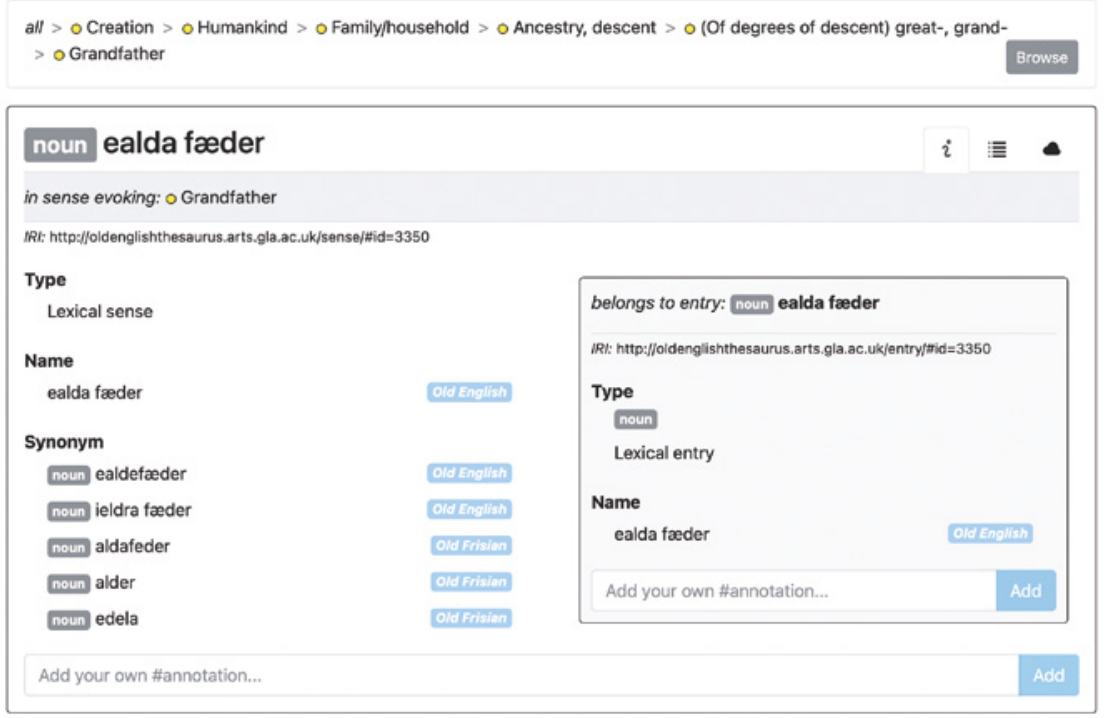

FIGURE 3 Information in Evoke on Old English ealda fceder in the sense of "02.03.02.03.04 | o1 Grandfather"

to the social statuses and roles of kinsmen (Fox, 1984: 243). Similar cultures often have very similar reference terms for relatives. It would go beyond the scope of this article to perform an entire analysis of the semantic field in question. However, to illustrate the usefulness of Evoke in comparing Old Frisian and Old English we undertake an exploratory comparative study of cosanguineal KINSHIP terms. We have taken inspiration from well-known research by Lancaster on kinship terminology (1958). Her kinship tree graph, which contains cosanguineal nomenclature in Old English, has been expanded here with corresponding Old Frisian lexis (see Figure 4). The graph, using a genealogical structure, contains nodes and lines to indicate individuals and relations of descent, respectively. ${ }^{17}$ For every node in the graph, Evoke has been employed to locate the corresponding Old English and Old Frisian words. The results are shown in Table 2.

17 It should be noted that genealogical structure of this graph differs from the structure found in $T O E$, which is onomasiological in nature and contains more than consanguineal terms. 


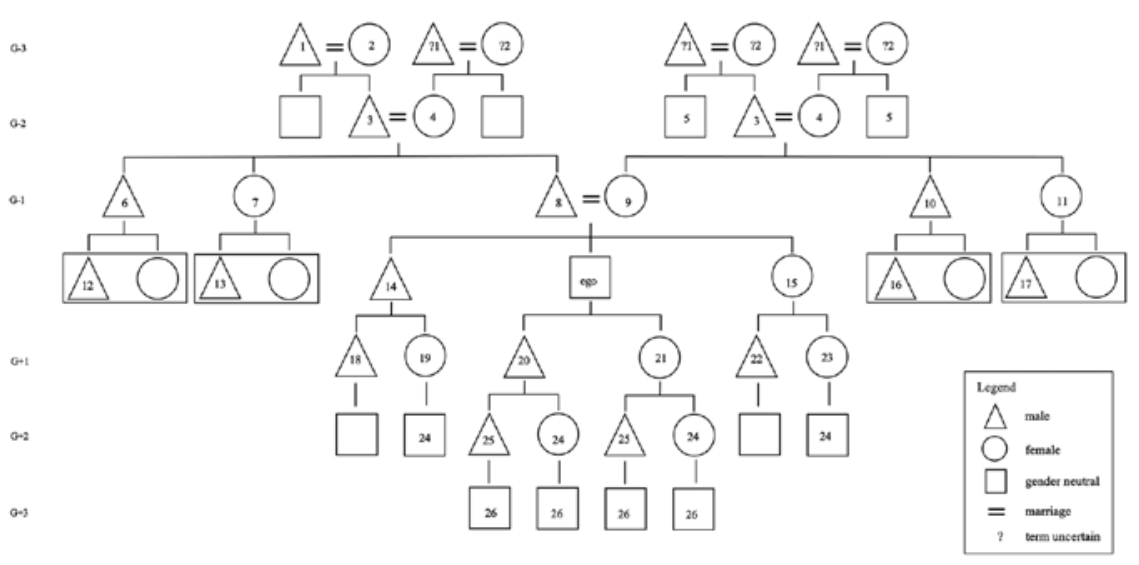

FIGURE 4 Kinship relations

TABLE 2 Cosanguineal kinship terms in Old English and Old Frisian

\begin{tabular}{|c|c|c|c|}
\hline No. & Old English & Old Frisian & Modern English \\
\hline 1 & ieldra fceder, thridda faeder & edela, ūraldafeder, alder & great-grandfather \\
\hline 2 & thridde mōdor & eldramōder, ūraldemōder & great-grandmother \\
\hline 3 & ealde mōdor & aldemōder & grandmother \\
\hline 4 & $\begin{array}{l}\text { ealdafceder, ieldra } \\
\text { fceder, ealda fceder }\end{array}$ & aldafeder, edela, alder & grandfather \\
\hline 5 & & aldaēm & granduncle \\
\hline 6 & fadera & federia,federesbrōther & uncle, father's brother \\
\hline 7 & fathu & fethu,federswester & aunt, father's sister \\
\hline 8 & faeder & feder & father \\
\hline 9 & $\begin{array}{l}\text { mōdor, äcennicge, } \\
\text { bearncennicge, } \\
\text { cennestre, byrthe }\end{array}$ & mōder & mother \\
\hline 10 & $\bar{e} a m$ & $\overline{\boldsymbol{e}} \boldsymbol{m}$, mōderesbrōther & uncle, mother's brother \\
\hline 11 & $\operatorname{mōdri}(g) e$ & mōdire, mōie & aunt, mother's sister \\
\hline 12 & $\begin{array}{l}\text { mōdri(ge), (ge)swēor, } \\
\text { geswigra }\end{array}$ & federiasune & $\begin{array}{l}\text { male cousin } \\
\text { (father's brother's son) }\end{array}$ \\
\hline 13 & $\begin{array}{l}\text { fathusunu } \\
\text { mōdri(ge), (ge)swēor, } \\
\text { geswigra }\end{array}$ & fethansune & $\begin{array}{l}\text { male cousin } \\
\text { (father's sister's son) }\end{array}$ \\
\hline 14 & brōthor & brōther & brother \\
\hline 15 & sweostor & swester & sister \\
\hline
\end{tabular}


TABLE 2 Cosanguineal kinship terms in Old English and Old Frisian (cont.)

No. Old English Old Frisian Modern English

16

17

18

19

20

21

22

23

24

25

26 emka, emessune

mōdiransune

neva, brōthersune,

brōtherbern, brōtherskind,

swesternabern

nifte, nifke, brōtheresdochter, niece

brōtherbern, brōtherskind,

swesternabern

sune, bern,

kind

dochter, bern,

kind

neva, swestersune,

swester(na)bern, swesterkind,

swesterling

nifte, nifke, swesterdochter, niece

swesterling

niftlin, niftakind

bernesbern, kindeskind

kindeskindeskind

great-grandchild

male cousin

(mother's

brother's son)

male cousin

nephew

son, child

(general term)

daughter, child

(general term)

nephew

niece's child

grandchild swester(na)bern, swesterkind,

(mother's sister's son)

granddaughter: nefe, nift

thridde dohtor

great grandson: thridda sunu

Comparison of the KINSHIP terminology clearly demonstrates the close relationship between Old English and Old Frisian: cognate forms for similar terms in Table 2 appear in boldface. Old English and Old Frisian have cognates for the lexis for: father $(\mathrm{Fa})$, mother (Mo), brother $(\mathrm{Br})$, sister $(\mathrm{Si})$, son $(\mathrm{So})$, daughter (Da), child, grandfather, grandmother, maternal uncle (MoBr) and aunt 
(MoSi), paternal uncle $(\mathrm{FaBr})$ and aunt $(\mathrm{FaSi})$, nephew and niece. Terms for some other blood relations likewise show similar cognate (compound) forms, i.e. great grandfather, greatgrandmother, cousins.

Old Frisian possessed terms for kinship relations that are not found in Old English: mōdiransune, emessune, aldaèm. When no Old English lexeme is recorded for a specific sense, it should not be inferred that the concept as such was absent in Old English. Notions such as "father's brother's son" and "mother's sister's son" exist in Old English, but are not lexicalized. Instead, they were expressed with genitival phrases (feederan sunu and modiran sunu).

\section{$6 \quad$ Analysis}

Based on the data from $T O E$ and the newly created dataset, this section presents a detailed analysis of both the Old English and the Old Frisian lexis located under the semantic field of "O2.03.02 Family/household" through the use of the web application Evoke. Evoke offers quantitative information from TOE, possibly in combination with additional datasets, in two forms: (1) basic statistics for a specific category and (2) advanced statistics that incorporate the onomasiological structure of TOE more fully, which also allow for queries to be customized.

\subsection{Analysis of Parts of Speech Distribution}

The basic statistics of Evoke allow us to provide some insight into matters such as the distribution of the parts of speech within the semantic field of KINSHIP, represented by the TOE category "O2.03.02 Family/household" and all its subordinate categories. Figure 5 shows the distributions for Old English senses and of Old Frisian ones. When contrasting these numbers, the percentages of nouns for Old English and Old Frisian turn out to be comparable. However, Old Frisian has relatively fewer adjectives and more verbs, adverbs, and phrases than Old English. The marked difference between the relative number of verbs and that of adjectives is especially striking and merits further research.

\subsection{Degree of Polysemy}

The advanced statistics section of Evoke renders, amongst others, a graph that indicates polysemy: the number of senses attributed to a lemma. Indeed, polysemy (and homonymy) can be a measure of the ambiguity of words, demanding the interpreting party to reflect carefully on the intended meaning in an utterance (Chandler and Munday, 2016: s.v. polysemy). Figure 6 demonstrates that, 

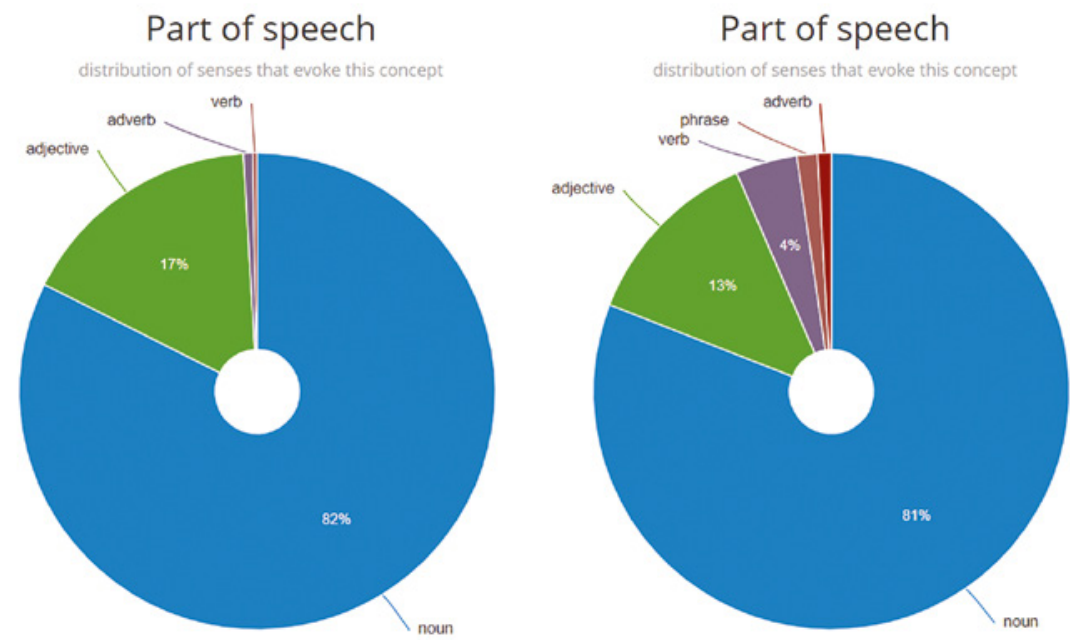

FIGURE 5 Distribution of Old English (left) and Old Frisian (right) senses in "O2.03.02 Family/household"

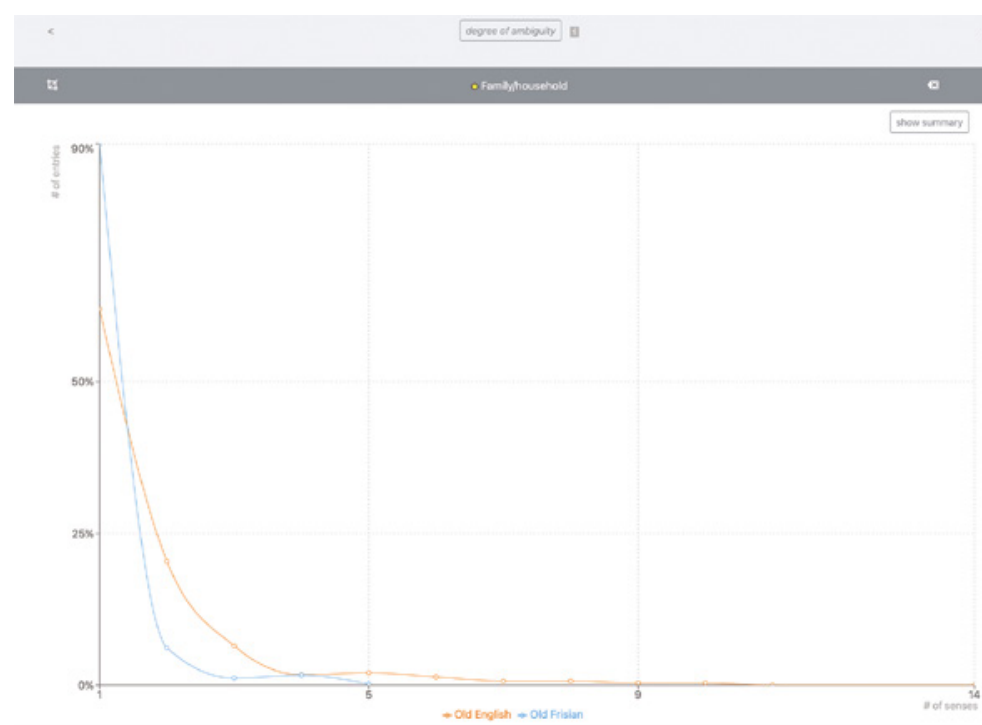

FIGURE 6 Degree of polysemy within "O2.03.02 Family/household"

within the taxonomy branch of "O2.03.02 Family/household", the vast majority of Old Frisian lemmata is monosemous (i.e., 90\% has a single recorded sense), whereas Old English has, relatively speaking, more lemmata that are polysemous. This outcome can partially be explained by the fact that $A F W B$, which was used to obtain the Old Frisian lemmata and senses, is a concise dictionary 
and therefore does not record senses extensively. Even so, $A F W B$ records multiple senses for entries when these senses are distinct enough to be necessary for initial readings of Old Frisian texts. The lack of polysemy for Old Frisian is striking, even when the nature of the source dictionary is taken into account. Whether this finding is characteristic of the language itself remains as yet undecided. The apparent monosemous nature of Old Frisian may be due to the lack of register variety in the surviving corpus. The Old Frisian corpus is predominantly juridical in nature whereas the Old English one is much more balanced, containing samples of different style varieties and registers, resulting in a higher number of polysemous words.

\subsection{Onomasiological Distribution over Taxonomy Levels}

Figure 7 shows the distribution of lexical senses over the various levels of the taxonomy, which is another advanced analysis offered by Evoke. ${ }^{18}$ This diagram indicates that Old Frisian has more recorded senses located at taxonomy levels with highly specialized meanings than Old English (see levels 8-12). Moreover, Old Frisian features senses that are allocated to levels beyond those in use for Old English (levels 10-12). Indeed, many of the categories newly created for the purposes of capturing KINSHIP in Old Frisian have been added as subordinate ones to TOE categories in the more specialized levels of the taxonomy. This diagram visualizes that outcome. A possible explanation may be that Old Frisian texts are mainly juridical in nature, very often pertaining to inheritance law, and therefore deal with more precise meanings that denote family relationships. A case in point is the degree of kinship, for which the Old Frisian lexis that has come down to us includes fine-grained senses (see also Table 2).

\subsection{Onomasiological Distribution over Categories}

Distributions over thesaurus categories yield data regarding the degrees of lexicalization (also known as cultural elaboration) of semantic fields, which enables comparisons between them (Wierzbicka, 1997: 10-11). Figure 8 charts such a distribution for the subcategories of "O2.03.02 Family/household", generated with the advanced statistics section of Evoke. ${ }^{19}$ The Y-axis has been

18 The diagram indicates a total of 221 Old Frisian senses for this semantic field rather than the 215 senses mentioned in section 5 . The disparity lies in the fact that six senses from $A F W B$ have been allocated to not one but two TOE categories, effectively creating two subsenses for each of these $A F W B$ senses when assigning them to the onomasiological structure of TOE (see Appendix A).

19 The diagram indicates a total of 220 Old Frisian senses spread over the semantic subfields. One of the senses from the 221 senses that one would expect (see previous footnote) is not found in the subfields but is allocated to the category "02.03.02 Family/household" itself, which accounts for the disparity. 


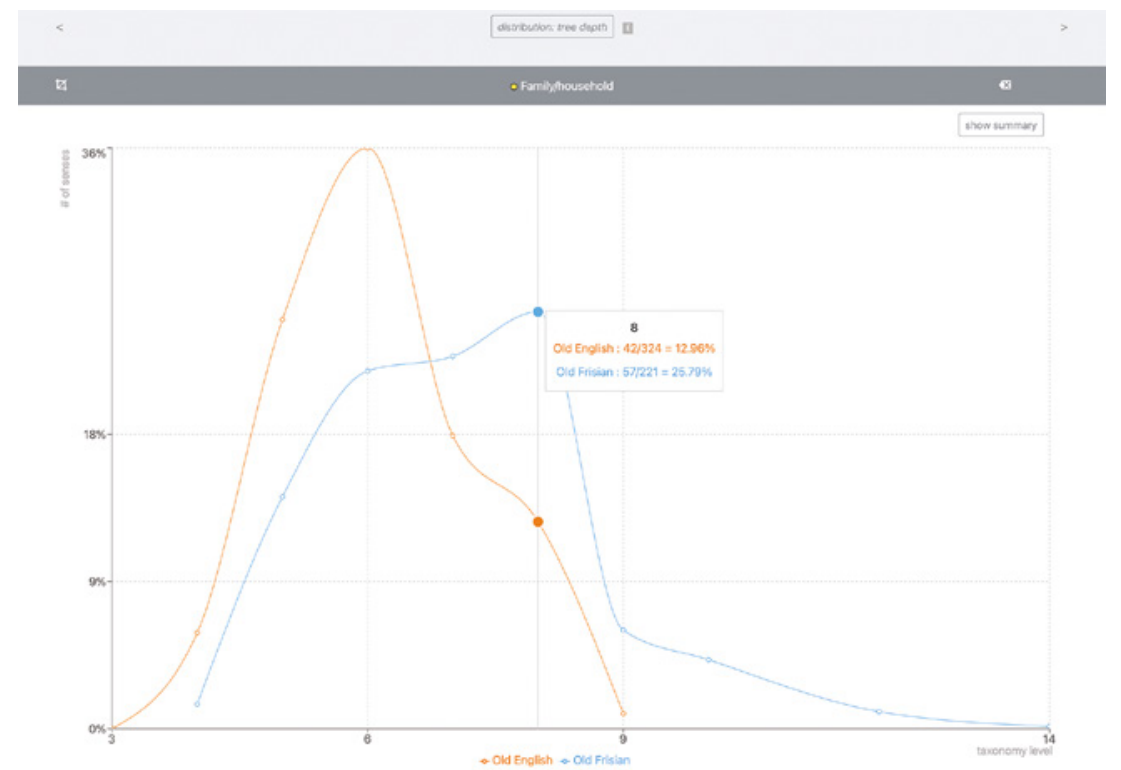

FIGURE 7 Distribution of lexical senses within "O2.03.02 Family/household" over the taxonomy levels

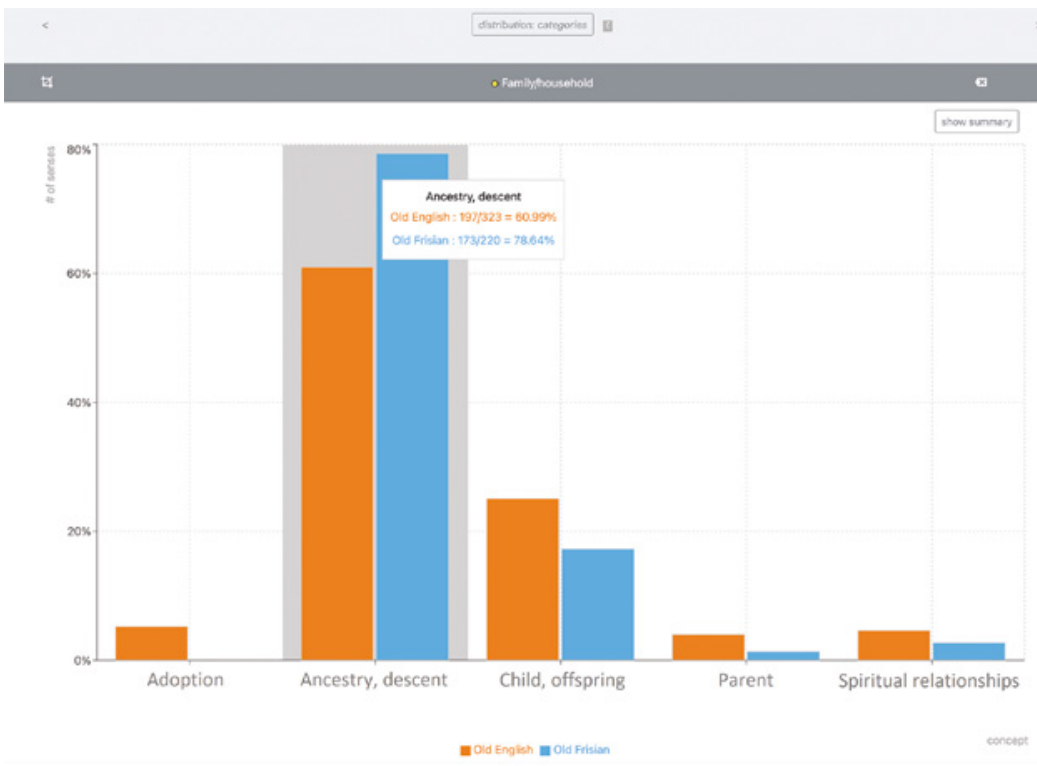

FIGURE 8 Distribution of lexical senses over the semantic subfields of "O2.03.02 Family/ household" 
configured to show the relative number of senses from a single language (i.e. Old Frisian or Old English) found within each branch indicated on the X-axis. The branch "O2.03.02.03 Ancestry, descent", highlighted in the diagram, contains the vast majority of the Old Frisian senses on KINSHIP (17O senses or $79 \%$ ). The majority of Old English senses is found in the same branch, albeit less dominant (61\%) in relation to the other branches within the field. In fact, "O2.03.02.03 Ancestry, descent" is the sole branch for which Old Frisian has a higher relative number of senses recorded than Old English. All other branchesi.e. "O2.03.02.04 Adoption", "02.03.02.02 Child, offspring", "02.03.02.01 Parent", and "02.03.02.05 Spiritual relationships" - have more Old English senses recorded than Old Frisian ones both in absolute and in relative numbers. The most striking differences between the two languages on this level are, therefore, (1) the relative degrees of lexicalization of "02.03.02.03 Ancestry, descent" and (2) the lack of any recorded Old Frisian senses for the concept of "O2.03.02.04 Adoption".

Apart from "02.03.02.04 Adoption", the Old Frisian corpus does not contain words for a number of other concepts found in Old English. These concepts are, most notably, represented by the TOE categories of "O2.03.02.04.01 Foster relationships", "02.03.02.02 | 06.01 A foundling”, "02.03.02.02.01 Twins", and "O2.03.02.02.02 Triplets". ${ }^{20}$ KInSH IP concepts that witness a larger degree of lexicalization in Old Frisian in comparison to Old English are those that have been newly introduced (see Appendix B), of course. However, they also include concepts that are gender neutral (such as expressed with Old Frisian swesterne 'sibling', for which TOE records no Old English equivalent) and concepts represented in TOE by the categories "O2.03.02.03.06.02.06 In-law relationships", "02.03.02.03.06.02.03 Child of brother/sister", "02.03.02.03.06.02.04 Cousin", and "02.03.02.02.05 | 02 A Bastard". 21

20 "Foster relationships" in TOE. Identifier: 1268. Location: 02.03.02.04.01. IRI: http://old englishthesaurus.arts.gla.ac.uk/category/\#id=1268.

"A foundling" in TOE. Identifier: 1123. Location: 02.03.02.02/o6.o1. IRI: http://oldenglish thesaurus.arts.gla.ac.uk/category/\#id=1123.

"Twins" in TOE. Identifier: 1127. Location: 02.03.02.02.01. IRI: http://oldenglishthesau rus.arts.gla.ac.uk/category/\#id=1127.

"Triplets" in TOE. Identifier: 1130. Location: 02.03.02.02.02. IRI: http://oldenglish thesaurus.arts.gla.ac.uk/category/\#id=1130.

21 "In-law relationships" in TOE. Identifier: 1256. Location: 02.03.02.03.06.02.06. IRI: http:// oldenglishthesaurus.arts.gla.ac.uk/category/\#id $=1256$.

"Child of brother/sister" in TOE. Identifier: 1239. Location: 02.03.02.03.06.02.03. IRI: http://oldenglishthesaurus.arts.gla.ac.uk/category/\#id=1239. 
An extensive analysis of the distributions found in the more specific levels of the taxonomy branches is beyond the scope of this article. Nevertheless, to show what results such an analysis may produce, we include some insights into one such distribution here. Figure 9 presents the dispersion for "02.03.02.02.05 Having the same parents", a subcategory of "O2.03.02.02 Child, offspring", which has a high degree of lexicalization for Old Frisian compared to Old English. ${ }^{22}$ Some interesting observations can be made about this diagram: Old Frisian has more words than Old English with senses of "O2.03.02.02.05.02 Sister" and "02.03.02.02.05 | O2 A Bastard". The latter is even expressed with a word specific to a child born before its parents were married: spilkind. The category "O2.03.02.02.05.03 Siblings" has been created for the Old Frisian lexis, since no

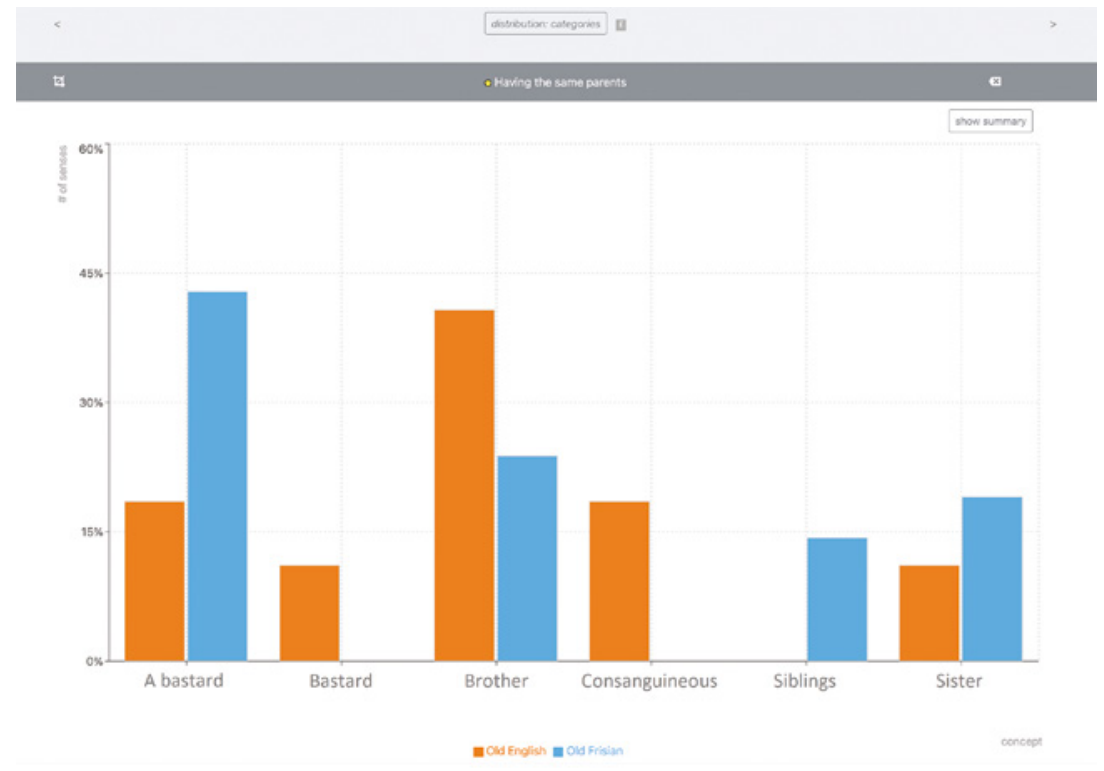

FIGURE 9 Distribution of lexical senses over the semantic subfields of "O2.03.02.02.05 Having the same parents"

"Cousin" in TOE. Identifier: 1247. Location: 02.03.02.03.06.02.04. IRI: http://old englishthesaurus.arts.gla.ac.uk/category/\#id=1247.

"A bastard" in TOE. Identifier: 1141. Location: 02.03.02.02.05/O2. IRI: http://oldeng lishthesaurus.arts.gla.ac.uk/category/\#id=1141.

22 "Having the same parents" in TOE. Identifier: 1136. Location: 02.03.02.02.05. IRI: http:// oldenglishthesaurus.arts.gla.ac.uk/category/\#id=1136.

"Child, offspring" in TOE. Identifier: 1113. Location: 02.03.02.02. IRI: http://oldenglish thesaurus.arts.gla.ac.uk/category/\#id=1113. 
Old English lexemes are recorded for this concept that leaves gender unspecified. The higher degree of lexicalization of both "02.03.02.02.05.02 Sister" and "02.03.02.02.05.03 Siblings" in Old Frisian compared to Old English, along with a lower degree for "02.03.02.02.05.01 Brother", suggests that the level of expressivity for this kinship tie is more alike for members of the male and female sex in medieval Frisia than in the Anglo-Saxon kingdoms. Further research is warranted into the question whether this hypothesis will hold when these semantic fields are compared for attestation of lexis in solely juridical texts, which constitute the majority of the surviving Old Frisian written legacy but only a fraction of the much vaster Old English corpus.

\section{$7 \quad$ Discussion}

The analyses and results in the previous sections are to be read in the context of the languages and resources that lie at their heart. Old Frisian and Old English are not contemporaneous languages: the surviving sources for Old Frisian are coeval with the period of Middle English. The observed contrasts in comparing these languages, however similar they may be, will therefore likely be influenced by the temporal as well as regional space between them. Likewise, it is important to bear in mind the nature of the corpora from which the lexicon was reconstructed. Surviving texts represent but a small portion of what must have been written, by a non-homogeneous group, and, perhaps more importantly, solely by those who were literate. Religious and administrative texts therefore represent a large portion of these medieval corpora, with certain genres more dominant than others (e.g., homilies in Old English, legal documents in Old Frisian).

The alignment of Old Frisian senses with the semantic hierarchy of тOE was complicated by differences between the lexicographic resources used (i.e. $A F W B$ for Old Frisian and $T O E$ for Old English) and the cultural contexts in which they were created. $A F W B$ and $T O E$ use different languages and practices to describe their lexicon: the former employs Modern German to define senses, the latter Modern English; $A F W B$ is a concise dictionary; TOE is based on more detailed dictionaries and demands sense differentiation to be of use. Allocating senses from one language to a taxonomy of a resource created for another, then, is by no means straightforward (see Appendix A for notes). As a result, observations with lingual comparisons, such as those made in this article, reflect differences between not only the language communities concerned, but also between the lexicographic practices that contributed to the frameworks used for interpretation of the lexis. 
In this study we set out to answer two questions. The first is whether it is possible to allocate the Old Frisian lexis within the semantic field of KINSHIP to the onomasiological macrostructure of TOE. The answer is in the affirmative. We have demonstrated that Old Frisian senses for KINSHIP can be viewed in an onomasiological structure, alongside Old English ones, by reusing the TOE macrostructure. However, the process of allocating senses from one language to a taxonomy of a resource created for another is by no means straightforward, as mentioned before. In addition to differences between the lexicographic practices for the two resources that have been aligned, a substantial number of Old Frisian senses, owing to their specialized meaning, demanded new categories to be fashioned and positioned into the taxonomy of TOE. For the domain of KINSHIP, these newly created categories could be slotted into lower, more specialized levels of the semantic hierarchy of TOE. The current research does not yet allow us to establish whether reuse and extension of an existing onomasiological structure was more time efficient than building one from the ground up. Of course, creating a new hierarchy, rather than reusing that of $T O E$, would have the disadvantage of forestalling onomasiological comparisons between Old Frisian and Old English. We surmise that adoption of semiautomated approaches (e.g., automated recognition of cognates) may be used in the future to significantly speed up the alignment process.

The second question that we have aimed to answer is whether Evoke, in combination with TOE, can offer new insights both for Old Frisian and, in contrast to Old Frisian, Old English. As demonstrated, there are a number of advantages to having Old Frisian lexis available in the onomasiological structure of a thesaurus. The first is that the resulting resource facilitates word field studies (comparable to those for which TOE has been used in the context of Old English) and comparative linguistic research (see the Results section). In fact, we expect the Old Frisian lexis to be accessible to a larger audience through Evoke, owing to the availability of Old Frisian senses in a digital resource that contains Modern English headings, using the TOE macrostructure, rather than in a dictionary that records sense definitions in German. A second advantage is that statistical analyses such as those enabled by Evoke lead to new knowledge of Old Frisian lexis. Preliminary analyses have already demonstrated that the field of KINSHIP in the surviving Old Frisian lexis consists of significantly fewer adjectives and more verbs compared to Old English; it contains lemmata that are mostly monosemous (90\%); it includes more fine-grained senses than Old English (including ones to denote different degrees of kinship); it has a relatively higher degree of lexicalization of the concepts of ancestry and 
descent than Old English; but it lacks any words for the concepts of adoption, foundling, twins, and triplets. Findings in Evoke lead to new questions that merit further research - into the surviving corpus and lexicographic practices, amongst others - to supply a satisfying context and better understanding. The availability of both Old Frisian and Old English lexis in Evoke, then, certainly offers a useful stepping stone to learn more about the nature of these kindred historical languages and their language communities.

\section{References}

$A F W B=$ Hofmann, D., and A. T. Popkema. Altfriesisches Handwörterbuch (Heidelberg: Universitätsverlag Winter, 2008).

Bajema, I. M. "The Mother's Brother: An Investigation into the Meaning of Old English eam." Neophilologus 78 (1994), 633-643.

Baker, P. S. Introduction to Old English (Chichester: Wiley-Blackwell, 2012).

Baldi, P. Linguistic Change and Reconstruction Methodology (Berlin and New York: De Gruyter Mouton, 2011).

Bammesberger, A. "Altfriesisch swâger." Indogermanische Forschungen 73 (1968), 133-135.

Boersma, U. J. "De frou yn 'e Fryske wetten." Us Wurk 10 (1961), 58-85.

Boutkan, D., and S. Siebinga. Old Frisian Etymological Dictionary (Leiden: Brill, 2005).

Bremmer Jr, R. H. "Insults Hurt: Verbal Injury in Late Medieval Frisia." In Approaches to Old Frisian Philology, eds. R. H. Bremmer Jr, T. S. B. Johnston, and O. Vries (Amsterdam: Rodopi, 1998), 89-112.

Bremmer Jr, R. H. "Language and Contents of the Old Frisian Manuscripts from Rüstringen (c.1300): A 'Veritable Mixtum Compositum'.' In Advances in Old Frisian Philology, eds. R. H. Bremmer Jr, S. Laker, and O. Vries (Amsterdam: Rodopi, 2007), 29-64.

Bremmer Jr, R. H. “Taking Stock of Old Frisian Studies: 1992-2021.” Us Wurk (2021), 1-28.

Bremmer Jr, R. H. "The Importance of Kinship: Uncle and Nephew in Beowulf." Amsterdamer Beiträge zur älteren Germanistik 15 (1980), 21-38.

Bremmer Jr, R. H. A Bibliographical Guide to Old Frisian Studies (Odense: Odense UP, 1992).

Bremmer Jr, R. H. An Introduction to Old Frisian: History, Grammar, Reader, Glossary (Amsterdam: John Benjamins Publishing Company, 20og).

Chandler, D., and R. Munday. A Dictionary of Media \& Communication, and edn (Oxford: Oxford University Press, 2016).

Colleran, R. A. B. Keeping It in the Family. Disentangling Contact and Inheritance in Closely Related Languages. Doctoral Dissertation (The University of Edinburgh, 2017). 
Dance, R. Review of TOE, Medium Avum 66 (2) (1997), 312-313.

Díaz-Vera, J. E. "Reconstructing the Old English Cultural Model for Fear." Atlantis 33 (2011), 85-103.

Diepeveen, A. "Verwantschapstermen in de Germaanse talen." Antwerp Papers in Linguistics 105 (Universiteit Antwerpen, 2003).

Durkin, P. "New Light on Early Middle English Borrowing from Anglo-Norman: Investigating Kinship Terms in grand-." Anglia 137 (2019), 255-277.

DWDS = Digitales Wörterbuch der deutschen Sprache (Berlin: Berlin-Brandenburgischen Akademie der Wissenschaften), https://www.dwds.de/d/wb-dwdswb.

Evoke = Stolk, S. Evoke (Web application, 2018), http://evoke.ullet.net/.

Fischer, A. "Of feederan and eamas: Avuncularity in Old English." In The Power of Words: Essays in Lexicography, Lexicology and Semantics in Honour of Christian J. Kay, eds. G. D. Caie, C. Hough and I. Wotherspoon (Amsterdam: Rodopi, 2006), 67-77.

Fox, R. Kinship and Marriage: An Anthropological Perspective, and edn (Cambridge: Cambridge UP, 1984).

Friel, B. M., and S. M. Kennison. "Identifying German-English Cognates, False Cognates, and Non-Cognates: Methodological Issues and Descriptive Norms." Bilingualism: Language and Cognition 4 (3) (2001), 249-74.

Görlach, M. Review of TOE, Anglia 116 (3) (1998), 398-401.

Hofmann, G., ed. Mittelalterliches Alltagsleben im Spiegel der altfriesischen Terminologie: mit Ergänzungen aus zeitgenössischen niederländischen Quellen, Estrikken 98 (Kiel: Nordfriesische Wörterbuchstelle Christian-Albrechts-Universität, 2015).

Hough, C. "Old English weargbeorg." Notes and Queries 54 (4) (2007), 364-365.

Kok, W. "Houlik en earberens by us forfaers." It Beaken 9 (1947), 59-64, 67-73.

Lancaster, L. "Kinship in Anglo-Saxon Society: I." The British Journal of Sociology 9 (1958), 230-25o.

Lancaster, L. "Kinship in Anglo-Saxon Society: II." The British Journal of Sociology 9 (1958), 359-377.

Lowe, K. A. "Never Say nefa Again: Problems of Translation in Old English Charters." Neuphilologische Mitteilungen 94 (1993), 27-35.

Loyn, H. R. "Kinship in Anglo-Saxon England." Anglo-Saxon England 3 (1974), 197-209. Meijering, H. D. Chindh uuirdit uns chiboran. Over het woord 'kind' in het oudere Duits (Amsterdam: Vrije Universiteit, 1985).

Meijers, E. M. "Eine germanische Zählung der Verwandtschaftsgrade." Tijdschrift voor Rechtsgeschiedenis 6 (1925), 1-52.

Munske, H. H. Der germanische Rechtswortschatz im Bereich der Missetaten: Philologische und sprachgeographische Untersuchungen. I: Die Terminologie der älteren westgermanischen Rechtsquellen (Berlin: De Gruyter, 1973).

Munske, H. H. et al., eds. Handbuch des Friesischen. Handbook of Frisian Studies (Tübingen: Max Niemeyer Verlag, 2001). 
Ojanguren López, A. E. "Old English Try Verbs: Grammatical Behaviour and Class Membership." Studia Neophilologica (2021), 1-19.

Otwinowska-Kasztelanic, A. "Awareness and Affordances: Multilinguals Versus Bilinguals and Their Perceptions of Cognates." In New Trends in Crosslinguistic Influence and Multilingualism Research, eds. G. De Angelis and J. M. Dewaele (Bristol and Blue Ridge Summit: Multilingual Matters, 2011), 1-18.

Pfeffer, G. "The Vocabulary of Anglo-Saxon Kinship." L'Homme 27 (1987), 113-128.

Popkema, A. T. "Die altfriesischen Eidesbezeichnungen." In Advances in Old Frisian Philology, eds. R. H. Bremmer Jr, S. Laker, and O. Vries (Amsterdam: Rodopi, 2007), $325-356$.

Pospelova, K. “Old Frisian Compounds: Kinship Terms.” Žmogus ir Žodis 19 (2018), 79-96.

Rauer, C. "Mann and Gender in Old English Prose: A Pilot Study." Neophilologus 101 (1) (2017), 139-158.

Roberts, J. “Towards an Old English Thesaurus." Poetica 9 (1978), 56-72.

Salmons, J. "What Old Frisian Can Tell Us about the History of i-Umlaut across West Germanic?" In Advances in Old Frisian Philology, eds. R. H. Bremmer Jr, S. Laker, and O. Vries (Amsterdam: Rodopi, 2007), 367-377.

Schmitt, N. "Vocabulary Learning Strategies." In Vocabulary: Description, Acquisition and Pedagogy, eds. N. Schmitt and M. McCarthy (Cambridge: Cambridge UP, 1997), 199-227.

Scott, P. "Conceptualising Olfaction: A Study of the Scent Nouns and Adjectives in Old English.” Studia Neophilologica (2021), 1-18.

Sjölin, B. "Zur Gliederung des Altfriesischen." Us Wurk 15 (1966), 25-38.

Spolsky, E. "Old English Kinship Terms and Beowulf." Neophilologische Mitteilungen 78 (1977), 233-238.

Sterringa, A. "The Most Miserable Women of All: Widows in Medieval Frisia." In Approaches to Old Frisian Philology, eds. R. H. Bremmer Jr, T. S. B. Johnston, and O. Vries (Amsterdam: Rodopi, 1998), 285-301.

Stroh, F. Handbuch der germanischen Philologie (Berlin: De Gruyter, 1985).

Tissari, H. "Current Emotion Research in English Linguistics: Words for Emotions in the History of English." Emotion Review 9 (1) (2017), 86-94.

$T O E=$ Roberts, J., and C. Kay with L. Grundy. A Thesaurus of Old English (Glasgow: University of Glasgow, 2017), http://oldenglishthesaurus.arts.gla.ac.uk/.

Trask, R. L. Trask's Historical Linguistics, ed. R. McColl Millar. 3rd edn (London and New York: Routledge, 2015).

Van de Poel, R. Corpus Oudfries (2019), http://corpora.ato.ivdnt.org/corpus-frontend/ OFR/.

Versloot, A. P. "Mechanisms of Language Change: Vowel Reduction in 15th Century West Frisian." Doctoral dissertation (University of Groningen, 2008). 
Versloot, A. P. "Why Old Frisian Is Still Quite Old." Folia Linguistica Historica 38 (2004), $253-298$.

Vries, O. "Die altfriesischen Urkunden." In Handbuch des Friesischen. Handbook of Frisian Studies, eds. H. H. Munske et al. (Tübingen: Max Niemeyer Verlag, 2001), 594-6o1.

Wierzbicka, A. Understanding Cultures through Their Key Words: English, Russian, Polish, German, and Japanese (Oxford: Oxford University Press, 1997).

Zeilfelder, S. "Das Wortfeld 'Mensch'. In Deutsche Wortfeldetymologie in europäischem Kontext, Band 3: Mensch und Mitmensch, ed. R. Lühr (Wiesbaden: Reichert, 2015), 33-110.

\section{Appendix A: Notes on the Alignment}

This appendix provides notes on the alignment between the Altfriesisches Handwörterbuch (АFWB) and A Thesaurus of Old English (TOE) for the semantic field of KINSHIP.

\section{A.1 AFWB Lemmata or Senses Discarded or Updated}

- The second sense recorded in $A F W B$ for evenkne, i.e. "Verwandter" [relative], is disputable and has therefore been discarded.

- Senses recorded in $A F W B$ for bern and kind do not reflect that they are synonyms. With the help of the online corpus of Old Frisian, it is easy to find instances that attest to the conclusion that bern and kind have the same senses, i.e. 1) Foetus, 2) Offspring (first degree), 3) Descendant and 4) Young, immature person. We have therefore chosen to align the senses of bern and kind with each other.

- The recorded sense in $A F W B$ for unnatlik, i.e. "unebenbürtig" [not equally related], is inaccurate and should be "not related."

- The senses of Old Frisian kennemech has been aligned with those of keremech.

\section{A.2 Lemmata or Senses Introduced}

The following terms were not recorded in $А F W B$ but are attested in the Old Frisian corpus and were added to the dataset used in this article.

- sex honda as a phrase with the sense "First degree blood relatives".

- thredda as a noun with the sense "Third generation".

The phrase sex honda is found in 7 manuscripts, in one of the most widely distributed texts known as the Twenty-four Land Laws. ${ }^{23}$ Thredda is recorded in the $A F W B$ as

23 This sense is attested in the following Old Frisian text witnesses: PnB-E3, L24-H2, L24-J, L24-R1, L24-E1, L24-F, JF-Ro. See results of a search for "sex hond" in Corpus Oudfries. 
numerical form with the general sense of dritte [third], but the more specialized sense of "third generation" is also recorded in the Old Frisian sources. ${ }^{24}$

\section{A.3 Remarks on Placement of Senses in TOE}

- Definitions in $A F W B$ of a number of Old Frisian senses on KINSHIP contained elements that made it possible to allocate these senses to fields outside of KINSHIP, too. Instead of allocating them to multiple semantic fields, these senses were allocated solely to categories in KINSHIP. The Old Frisian lemma kniaia, for instance, has a sense of "lawfully claiming to be related". This sense was allocated to KINSHIP in TOE only, but not additionally to the semantic field of "14.03.03 n. Law, action of the courts". 25 Similarly, lemmata with the sense of "being related" or "relationship" were not allocated to the semantic field of "o8.01 n. Heart, spirit, mood, disposition" in $T O E .^{26}$

- The $A F W B$ lemma kniaia has three overlapping senses: "Verwandschaft nachweisen," "Verwandschaft geltend machen," "verwandt sein." We merged these three into one sense in English: "To (claim to) be related."

- Senses defined as "Blutverwandt" or "Verwandt" are used indiscriminately in the $A F W B$. These senses have all been aligned as "Related." Similarly, the $A F W B$ uses "Blutverwandtschaft" and "Verwandtschaft" indiscriminately. Blood relations and blood relatives all belong to TOE category "Close relationship."

\section{A.4 Comments on the Structure of TOE}

In the following paragraphs we illustrate some of the difficulties experienced when placing the Old Frisian senses from $A F W B$ within the categories from TOE.

- The $A F W B$ records a single sense for the Old Frisian lemma dochter with its definition in German: "Tochter" [daughter]. TOE records the Old English cognate dohtor in different senses: one is listed in the category "O2.03.02.02.04 A daughter", another in the category "O2.03.02.03.05 $102 \mathrm{n}$. Female descendant". ${ }^{27}$ The Old Frisian lemma's meaning refers to both of these. The question arises as to whether one should allocate the single recorded sense of Old Frisian dochter to the same two categories as

24 This sense is attested in the following Old Frisian text witnesses: LaFi-F, PnB-B2, Dom-J, BHuB, Lav-H2, LaFi-Ro. See results of a search for "thredda" in Corpus Oudfries.

25 "Law, action of the courts" in TOE. Identifier: 19453. Location: 14.03.03. IRI: http://old englishthesaurus.arts.gla.ac.uk/category/\#id=19453.

26 "Heart, spirit, mood, disposition" in TOE. Identifier: 13458. Location: o8.o1. IRI: http:// oldenglishthesaurus.arts.gla.ac.uk/category/\#id $=13458$.

27 "A daughter" in TOE. Identifier: 1133. Location: 02.03.02.02.04. IRI: http://oldenglishthe saurus.arts.gla.ac.uk/category/\#id=1133.

"Female descendant" in TOE. Identifier:1193. Location:02.03.02.03.05/O2. IRI: http://old englishthesaurus.arts.gla.ac.uk/category/\#id=1193. 
Old English dohtor. Since it is obvious that a daughter is also a female descendant, a sense that is also part of KINSHIP, we have decided to allocate the recorded sense in $A F W B$ to both categories. An alternative solution would be to create two subsenses of the $A F W B$ lemma and have allocated these to their respective categories.

- The senses of the cognate words Old English föemne and Old Frisian fomne are related but still slightly different (see Table Ai).

TABLE A1 föemne and fomne

\begin{tabular}{|c|c|c|c|}
\hline Lemma & TOE categories & & \\
\hline \multirow[t]{2}{*}{ Old English fäemne } & $\begin{array}{l}\text { Female person, } \\
\text { woman }\end{array}$ & Girl & $\begin{array}{l}\text { A maiden, } \\
\text { A virgin }\end{array}$ \\
\hline & AFWB senses & & \\
\hline Old Frisian fomne & 1) Mädchen [girl] & $\begin{array}{l}\text { 2) Tochter } \\
\text { [daughter] }\end{array}$ & $\begin{array}{l}\text { 3) Magd } \\
\text { [female servant] }\end{array}$ \\
\hline
\end{tabular}

When looking at the TOE categories for fōmne, the category "O2.03.01.02 Female person, woman" is a sense more general than those recorded in $A F W B .{ }^{28}$ Although the lemma may fit in this category, too, we have decided to keep the three senses recorded in $A F W B$ unchallenged, positioning only these in the semantic hierarchy of TOE On KINSHIP.

\section{A.5 Inconsistencies AFWB}

The senses of (near-)synonyms and other semantically related words have some inconsistencies. Cases in point are Old Frisian wiff and frouwe.

wïf n. 1) Weib; 2) Frau

frouwe, frowe, frou ${ }^{\mathrm{WL}}$ f. 1) Frau; 2) Ehefrau; 3) Edelfrau, Fürstin; 4) Herrin; 5) die Jungfrau Maria; 6) Schwiegermutter

Examination of the contexts in which the lexemes wiff and frouwe occur reveals that the compilers of the $A F W B$ have tried to reflect the connotational differences that the two words have in the German descriptions. Frouwe was a term used to denote respect, while wiff was the more generally used word. For frouwe only the senses 1, 2

28 "Female person, woman" in TOE. Identifier: 1079. Location: 02.03.01.02. IRI: http://oldeng lishthesaurus.arts.gla.ac.uk/category/\#id=1079. 
and 6 have been allocated to KINSHIP in TOE (the others fall outside the scope of our investigation). Corresponding TOE categories are "O2.03.01.02 Female person, woman" and "12.09 | 07.05 n. Wife, married woman." 29

\section{A.6 Allocation of AFW Senses to Multiple Tов Categories}

Six senses from $A F W B$ have been allocated to not one but two TOE categories, effectively creating two subsenses for each of these $A F W B$ senses when assigning them to the onomasiological structure of TOE. The allocation to a second TOE category allowed, most notably, for words denoting offspring (such as "son" or "daughter") to be marked as "descendant", too. The six $A F W B$ senses, along with their allocations in TOE, are in Table A2.

TABLE A2 Six senses

\begin{tabular}{|c|c|c|c|c|c|}
\hline \multicolumn{4}{|c|}{$A F W B$} & \multicolumn{2}{|c|}{ TOE } \\
\hline Lemma & Sense no. & Sense & $\begin{array}{l}\text { Mod. English } \\
\text { translation }\end{array}$ & Category 1 & Category 2 \\
\hline dochter & 1 & Tochter & daughter & A daughter ${ }^{a}$ & Descendant $^{\mathrm{b}}$ \\
\hline kind & 2 & $\begin{array}{l}\text { Kind, } \\
\text { Nachkomme }\end{array}$ & $\begin{array}{l}\text { child, } \\
\text { descendant }\end{array}$ & $\begin{array}{l}\text { Child, } \\
\text { offspring }\end{array}$ & Descendant \\
\hline knapa & 2 & Sohn & son & A son ${ }^{d}$ & Descendant \\
\hline sunder_1 & 1 & Sohn & son & A son & Descendant \\
\hline sune & 1 & Sohn & son & A son & Descendant \\
\hline slachte_1 & 2 & Familie & family & Ancestrye & Kinsman/relative \\
\hline
\end{tabular}

a "A daughter" in TOE. Identifier: 1133. Location: 02.03.02.02.04. IRI: http://oldenglishthesaurus.arts.gla .ac.uk/category/\#id=1133.

b "Descendant" in TOE. Identifier: 1191. Location: 02.03.02.03.05. IRI: http://oldenglishthesaurus.arts.gla .ac.uk/category/\#id=1191.

c "Child, offspring" in TOE. Identifier: 1113. Location: 02.03.02.02. IRI: http://oldenglishthesaurus.arts.gla .ac.uk/category/\#id=1113.

d "A son" in TOE. Identifier: 1131. Location: 02.03.02.02.03. IRI: http://oldenglishthesaurus.arts.gla.ac.uk/ category/\#id=1131.

e "Ancestry" in TOE. Identifier: 1159. Location: 02.03.02.03. IRI: http://oldenglishthesaurus.arts.gla.ac.uk/ category/\#id=1159.

f "Kinsman/relative" in TOE. Identifier: 1208. Location: 02.03.02.03.06.01. IRI: http://oldenglishthesaurus .arts.gla.ac.uk/category/\#id=1208.

29 "Wife, married woman" in TOE. Identifier: 18618. Location: 12.09/07.05. IRI: http://oldeng lishthesaurus.arts.gla.ac.uk/category/\#id=18618. 


\section{Appendix B: Old Frisian Lemmata on Kinship Aligned with $A$ Thesaurus of Old English}

Categories in italics are ones that did not exist in the original thesaurus taxonomy and have been newly created to accommodate Old Frisian senses.

02.03.02 Family/household (id: 1108)

IRI: https://oldenglishthesaurus.arts.gla.ac.uk/category/\#id=1108

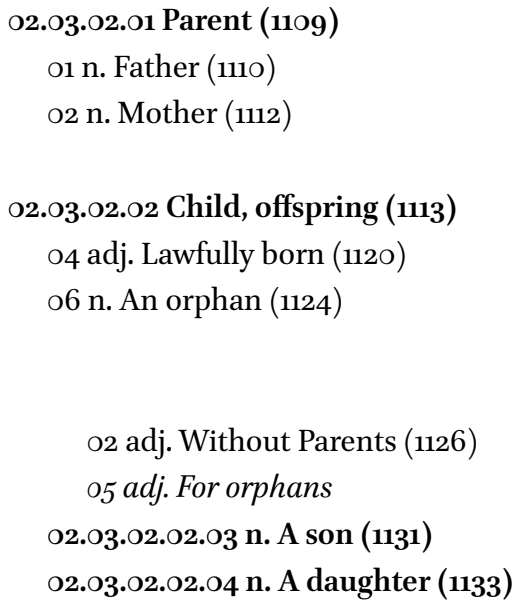

alder

feder

mōder

bern, kind

aftberen

wēsa, wēsekin, wēsekind, wēseklēn, wēstien

alderlās, biwēsed, wēsid wēslik knapa, sunder, sune fomne, dochter

basterd, hōringe, hōrkind, hōrning, hōrbrēd, hōrbern basterdbrōther basterdswester spilkind brōther brōtherlik brōtherlikhēd fulbrōther halfbrōther swester fulswester halfswester swesterskip swesterne fulswesterne halfswesterne 
o2.03.02.03 Ancestry, descent (1159)
o2 Side (1162)
o3 Generation, degree of descent (1163)

o2 Third generation

o3 Descendance

or $v$. To descend

o2 adj. Descending, down

o3 adv. Descendingly

o4 Ascendance

orv. To Ascend

o2 adv. Ascendingly, backwards, up

${ }_{5}$ Part of a family tree

o6 Trunk of a family tree slachte

sīde

grād, gung, knī, lith, sibdēl, siā,

slachte, sibdēl

thredda

delgung, nithergung, tōdele

delgunga, nithergunga,

tōdelgunga

delgungande

tōdele

upgung

upgunga, ūrbekgunga

ūrbek

facht

stipa

02.03.02.03.01 Ancestry, paternal kinship (1166)

o2 Male line of descent (1169)

o3 Father's side (1170)

sperehond, swerdsīde

o1 adj. Paternal (1171)

federsīde

o2 n. Father's mother side

fetherlik

federesmōdersīde

02.03.02.03.02 Maternal descent (1172)

o2 Female line of descent (1174)

spindelsīde

o3 Mother's side (1175)

mōdersīde

o1 adj. Maternal (1176)

mōderlik

04 n. Mother's father side

mōderfedersīde

02.03.02.03.03 Forefather, ancestor (1178)

alder, forefeder, forefirdera

02.03.02.03.04 (Of degrees of descent) great-, grand- (1182)

o1 n. Grandfather (1183)

o2 n. Grandmother (1184)

o3 n. Great grandfather (1185)

o4 n. Great grandmother (1186)

og n. Granduncle

02.03.02.03.05 Descendant (1191) aldafeder, alder, edela

aldemōder,

ūraldafeder, alder, edela

ūraldemōder

aldaēm

bern, kind, knapa, neikuma, neikumande, neikumeling, neikumer, sunder, sune 


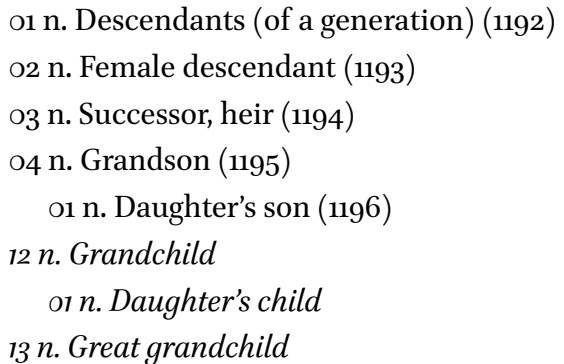

02.03.02.03.o6 Kinship, relationship (1204) o1 adj. Related (1205)

02.03.02.03.o6.o1 Kinsman, relative (1208)

o3 n. Paternal relative (1212)

o4 n. Maternal relative (1213)

o7 n. Next of kin (1216)

o9 n. Kinsfolk (1218)

o5 n.Relationship through common parents or adj. Rel. through common parents o6 $n$. Relationship by one parent

$11 n$. Third degree relative

$12 \mathrm{n}$. The six first degree relatives

$13 n$. Relative in the same degree

$14 n$. Relative chosen for oath swearing

15n. Relative in ascending line

16 n. Relative in descending line

\subsection{Close relationship (1224)}

o1 adj. Closely related (1225)

o2 adj. Like relatives

o3 n. Blood relations (1230)

$04 \mathrm{adj}$. Not related (1233)

${ }_{0}$ v. To (claim to) be related

or v. to (claim to) be closer related

o6 adj. Nearest related neikuminge

dochter

outside of current scope

dochtersune

bernesbern, kindeskind

dochteresbern

kindeskindeskind

sibbe_1, blōd, wirtel

bisib, bisibbed, sibbe_2, swēs,

liāf, nātlik

sibba, sibdēl, kniā, knīling, mēch, friund, nāt, holda federfriund, federmēch, federsibbe mōderfriund, mōdermēch nesta

sibbe_1, slachte, ken

fulsibbe

fulsibbe

halfsibbe

thredkniā, thredknīling,

thredling, thredsiā

sex honden

evenknē, evenkniā, evenknīling,

lìkenisse

keremēch, kestfriūnd

upstīger

nītherstīger

biefta, inlik, niār

swēslik

blōd, bērena blōd

fremede, unnātlik

kniāia

bikniāia, ūrkniāia, ūtsteka

allerswesest, allersibbest, nest 
07 adj. Too close related (incest)

o8 adj. More distantly related

02.03.02.03.06.02.01 Uncle (esp. maternal)

(1234)

o1 n. Paternal uncle (1235)

o1 $n$. Father's halfbrother

02.03.02.03.06.02.02 Aunt (1236)

o1 n. Maternal Aunt (1237)

o2 n. Paternal Aunt (1238)

02.03.02.03.06.02.03 Child of brother/sister (1239)

o1 n. Sister's child (1240)

o2 n. Nephew (1241)

o1 n. Sister's son (1242)

o2 n. Brother's son (1243)

o3 n. Niece (1244)

o1 n. Brother's daughter (1245)

$02 n$. Sister's daughter

o3 n. Niece's child

o5 n. Brother's child

02.03.02.03.06.02.04 Cousin (1247)

o2 n. Father's sister's son (1249)

o4 $n$ Relationship between cousins

o5 n. Mother's brother's son

o6 n. Mother's sister son

o7 n. Father's brother's son

o8 n. Children of cousin sibbe_2

ùtlik

ēm, mōderesbrōther

federia

halffederia

mōdire, mōie

fethe, federesswester

swesternabern

swesterbern, swesterling,

swesterkind

neva

swestersune

brōthersune, neva

nifte, nifke

brōtheresdochter

swesterdochter

niftlin, niftakind

brōtheresbern, brōthereskind

fethansune

berning, swire

ēmka, ēmessune

mōdiransune

federiasune

efterswesterling,

efterswesternabern,

ōtherswesterbern

02.03.02.03.06.02.05 Step relationships (1251)

o1 n. Step-father (1252)

o2 n. Step-mother (1253)

o3 n. Step-son (1254)

o4 n. Step-daughter (1255)

o5 n. Step-child stiāpfeder

stiāpmōder

stiāpsune

stiāpdochter

stiāpkind 
02.03.02.03.06.02.06 In-law relationships

(1256)

o1 n. Father-in-law (1257)
o2 n. Mother-in-law (1258)
o3 n. Daughter-in-law (1259)
or n. Being a daughter-in-law
o4 n. Brother-in-law (126o)
o6 n. Son-in-law/brother-in-law (1262)
o7 n. Son-in-law and father-in-law (1263)
o8 n. Son-in-law
or n. Being a son-in-law
og n. Parents-in-law

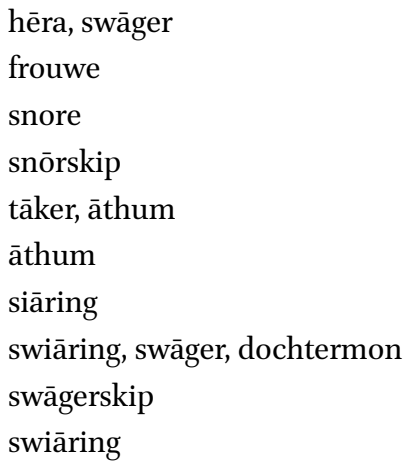

02.03.02.04 Adoption (1264)

02.03.02.04.01 Foster relationships (1268)

02.03.02.05 Spiritual relationships (1274)

o1 adj. Spiritual (1275)

fadersibbe, faderskip

gāstlik

o2.o1 n. A godfather (1277)

fadera

05 n. Relationship betw. godbrother and biological

brother

brōtherlikhēd

o6 n. Relationship betw. godfather and biological

father

fēderlikhēd

\section{B.1 Other ToE Categories Containing Old Frisian Lemmata}

As mentioned in section 5 , a number of Old Frisian lemmata on KINSHIP have been classified within TOE outside of the semantic field "O2.03.02 Family/household", and are therefore not included in our current analyses and case studies. The classification of these 47 lemmata is provided below.

O2.o1 Existence, life (id: 661)

IRI: https://oldenglishthesaurus.arts.gla.ac.uk/category/\#id=661

02.01.03 Fruitfulness, fertility (698)

02.01.03.05 To be fruitful, to produce (705) forthbrenga

02.01.03.02 Barrenness, sterility (717)

o2 adj. Barren, unproductive (719) tochtalās 
02.01.03.03.01 To beget (730)

o2 n. Begetting of children (732)

berntām, berntochta

o6 n. An embryo/foetus (738)

berde, bern, kind

og adj. Pregnant (742)

12 adj. Childless (745)

bernheftich

bernlās

02.01.03.03.02 To bring forth, produce (747)

$05 \mathrm{n}$. Produce, fruit, offspring (752)

frucht

02.01.03.03.03 Birth (761)

berde

o1 v. To be born $(762)$

bera_1

o2 adj. Born (763)

beren

02.01.03.03.03.01 Child-bearing, childbirth (768)

o7 n. A miscarriage (776)

tām

bernwendene,

berdwendene, dāden frucht

02.01.03.03.04 Offspring, race, breed, family,

children (780)

not included

ol n. Progeny, offspring (781)

tām

o2 n. Descendants, progeny, race (784)

not included

o1.01.03.03.06 Sex, kind (789)

o1 n. A sex (79o)

o1.01.01 n. A Male (793)

mon

02.01 n. A Female (795)

frouwe, wif

O2.03 Humankind (id: 1059)

geslachte, slachte_1

IRI: https://oldenglishthesaurus.arts.gla.ac.uk/category/\#id=1059

02.03.01 People (1065)

o1 n. Human being (1066)

o9 v. To have (a brother, husband etc.) (1075)

02.03.01.o1 Male person, man (1076)

o2 adv. In a male manner (1078) menneska

mon, menneska

habba

mon, hēra, monnesnoma, monnespersōne

monlike 
02.03.01.02 Female person, woman (1079)

o3 adj. Female (1082)

02.03.01.04 Child (1086)

o5 n. Male child (1091)

o6 n. Female child (1092)

02.03.01.05 Youth, boy, stripling (1093)

02.03.01.07 Girl (1099) frouwe, wīf, wīfke, wīfnama, menneska, frouwespersōna frouwelik, wīflik

kind, kintien, mach, bern knapabern, knapakind fomnabern, fomnakind

knapa, mage

famke, fomne, megeth, meiden

12.09 Marriage, state of marriage (id: 186o2)

IRI: https://oldenglishthesaurus.arts.gla.ac.uk/category/\#id=186o2

o6 n. Married persons, married couple (18610) hiūne, sinhīgen

o7.03 n. Husband, (married) man (18615) mon

07.05 n. Wife, married woman (18618) wîf, wîfke, wîfnama, hūsfrouwe

12.09.03 Unmarried state (18657)

o2 A maiden, a virgin (18663) megeth

o3 An unmarried man (18665) knapa

12.09.05 State of a woman whose husband has died (18683)

o1 Relict, widow (18684) widwe

o2 Widower (18685) wedener 